\title{
The Syllabus Development of Welding Technology Course SKNNI-Based PTM-FT UNIMED to Support The SMAW Welding Competence Test
}

\author{
Hidir Efendi ${ }^{1}$, Izwar Lubis ${ }^{2}$, Firdaus ${ }^{3}$ \\ Department of Mechanical Engineering Education, FT Unimed, Medsn Indonesia ${ }^{1,2,3}$ \\ hidirefendi23@gmail.com
}

\begin{abstract}
This study aims to develop the Syllabus of Welding Technology Courses in the FT Unimed Mechanical Engineering Education Study Program (PTM) to Support Competency Test in Certification Institutions (LSP) with Level IV Qualification of Shielded Metal Arc Welding (SMAW). Specifically, this study aims to: (1) find the SKKNI-based Welding Technology Syllabus Draft Syllabus with the Skill Passport evaluation pattern up to level IV to support the competency test according to the demands of the Professional certification body, (2) find the Syllabus Validation of the Welding Technology Courses developed. by several learning experts / experts, and 3) discovering the effectiveness of syllabus application developed in learning on a limited and broad scale, and (4) disseminating syllabus developed to lecturers in the Department of Mechanical Engineering Education at FT Unimed. To produce operational products in the form of SKKNI-based Welding Technology Learning Syllabus, a process of research and development phase known as "the R\&D cycle" is guided by the ADDIE model and is carried out in a very limited time. In the first phase of the survey, a survey method was used through a needs assessment and literature study. The second stage, designing a draft of the Welding Engineering syllabus. The third stage used the trial method through expert review procedures, one-on-one trials, small group trials, and field trials (real classes). In the next stage is the Implementation and Dissemination and evaluation of products. Data collection techniques used in this study were non-test techniques in the form of questionnaire responses from students and expertlecturers.
\end{abstract}

Keywords: Syllabus, SKKNI, , SMAW Welding.

\section{Introduction}

Based on data from the Welding Association of Indonesia-Indonesian Welding Society (API-IWS) as reported in Kontan.co.id, 11 November 2017, that the development of the national manufacturing industry still requires 5,000 welding workers per year [1]. In line with this, Indonesia currently has 500 thousand welding workers, but only $10 \%$ have certificates that are recognized worldwide (https:// medaia-indonesia.com/read/detail/212116-indonesiaakanpenuhi-kekurangan-ahli-pengelasan- bertarafinternasional. In fact, he further stated that in 2030, the need for welding experts in the world requires at least 3.2 million people, while in Welding Camp itself as a training center for welding workers, only 2,500 people have been born since its establishment in 2015 , so this shortage is a great opportunity for prospective Indonesian welding experts. 
Mechanical Engineering Education Study Program (PS-PTM) of FT-Unimed is a form of formal education unit that organizes technical vocational education at the Diploma-3 (D3) and Bachelor (S1) levels. Besides preparing vocational students of Mechanical Engineering, graduates are also prepared to be able to take part in the welding industry services, in addition to other fields. Graduates are expected to take part in their fields both as workers and as job creators.

To be able to produce graduates as expected, quality learning references such as syllabus are needed. In relation to the relevance of welding employment, the structure and content of the syllabus must be aligned with the Indonesian National Work Competency Standards (SKKNI), both based on existing guidelines and the real reality of the real workplace. Likewise, the composition of the Syllabus must be in accordance with the Indonesian National Qualification Framework (KKNI). Thus the importance of the Syllabus of Welding Technology courses in order to meet welding work standards, it is necessary to reorganize the existing syllabus. Specifically, taking into account the needs of the field and the availability of available Fabrication Workshop equipment, the Syllabus was developed in the SMAW (Shielded Metal Arc Welding) by referring to the RI Minister of Manpower and Transmigration Number: KEP. 342 / MEN / X / 2007.

Syllabus is a learning plan for a particular group and / or group of subjects / themes that includes competency standards, basic competencies, subject matter / learning, learning activities, indicators, assessment, time allocation, and learning resources. In other words, the syllabus is a translation of competency standards and basic competencies into subject matter / learning, learning activities, and indicators of competency achievement for assessment (BSNP, 2006). The syllabus is used as a reference in preparing the Semester Program Plan (RPS) and Lecture Event Unit (SAP) which subsequently serves as a guideline for conducting lectures in class, related to Student and Lecturer activities for one semester. Syllabus is a set of plans and arrangements regarding learning activities, classroom management, and assessment of learning outcomes. The syllabus contains the main components that can answer the following questions: competencies that will be instilled to students through a learning activity, activities that must be carried out to instill/shape these competencies, efforts that must be made to know that the competencies are already owned by students, useful as a guide in the development of further learning, ranging from learning planning, learning management, and developing an assessment system.

In developing a syllabus it is necessary to pay attention to eight principles, namely: ((1) Scientific, (2) Relevant, (3) Systematic, (4) Consistent, (5) Adequate, (6) Actual and Contextual, (7) Flexible, and ( 8) Comprehensive (BSNP, 2006) Scientific shows that all material and activities which are content in the syllabus must be correct and scientifically accountable Relevant related to the scope, depth, level of difficulty and sequence of presentation of material in the syllabus according to students' needs., syllabus components are functionally interrelated in achieving competency Consistent namely the existence of a consistent relationship between basic competencies, indicators, subject matter, learning experiences, learning resources, and assessment systems Adequate, coverage of indicators, subject matter, learning experiences, sources learning, and the assessment system is sufficient to support the achievement of basic competencies, actual and contextual, that the coverage of indicators, subject matter, learning experiences, resources learning, and assessment systems pay attention to the development of science, technology, and events that occur. Flexible, the entire syllabus component can accommodate the diversity of students, educators, and the dynamics of changes that occur in schools and community demands. And Completely interpreted that, the syllabus component covers the whole domain of competence (cognitive, affective, and skills). 
Resarch Development that refers to the ADDIE model is a development model with several stages. The stages of the ADDIE Model are (Gagne, 2015): (a) Analize (analysis), conducting need assessments, (b) Design (design), relating to learning objects, assessment instruments, exercises and their contents, subject analysis, learning plans, and learning media, (c) Development, the process of making a draft of a design come true or the product that will be used, (d) Implementation (implementation / execution), which is a concrete step to implement the learning system that we are making and (e) Evaluation (evaluation / feedback), is a process to see whether the learning system that is being built can be successful. The ADDIE development model is a learning design model based on an effective and efficient system approach and an interactive process that is the results of the evaluation of each phase can take the development of learning to the next phase. The final result of a phase is the initial product for the next phase.

Welding Technology courses are courses that contain Theory and Practice competencies. This course is held in 2 (two) semesters with the name of the Welding Technology course in the initial semester and Advanced Welding for the following semester. Welding Technology courses are compulsory courses in the Study Program, whereas Advanced Welding courses are elective courses SKKNI is the formulation of work ability that covers aspects of knowledge, skills and / or expertise as well as work attitudes that are relevant to the implementation of the duties and conditions of the position stipulated in accordance with applicable laws and regulations and are arranged based on the needs of the business field [3]. With the competency standard mastered, then someone will be able to: (1) How to do a job, (2) How to organize it, (3) What to do, (4) How to use abilities, (5) How to use the abilities they have.

In the framework of developing the quality of the workforce, KKNI is determined based on the level of work competency qualifications from the lowest (qualification certificate 1) to the highest (qualification certificate 9), however not all levels in the IQF can be filled by certain types of work competencies in the sector or sector [2]. It was further explained that in qualifications competencies could be arranged as tiered qualifications or as non-tiered qualifications. Specifically for this study, it was conducted based on tiered qualifications. This means that the contents of the learning syllabus are arranged according to the SMAW / GMAW Welding competency qualification level starting from Level I up to. Level IV [3].

The evaluation (competency test) on SKKNI can be done in two ways, namely a tiered and not tiered competency test. Non-tiered competency tests are carried out for certain professions that only require certain competencies according to those contained at that level (Kepmenakertrans Number: KEP / 342 / X / 2007). After completing learning at a certain level, participants can take competency tests at that level. However, participants cannot take the next level of competency test, if the participant is not yet competent at the previous level. If a participant has been declared competent, he / she can take the next level up to level IV, and a certificate is given after the competitor has been declared competent at all levels. This evaluation method in SKKNI is called the Skill Passport.

\section{Research Methods}

This research was conducted at the Mechanical Engineering Education Study Program Faculty of Engineering, State University of Medan, for 1 (one) semester in the odd semester 2019/2020. The research targets were students of the 2018 PTM S1 Study Program who were teaching Welding Technology courses 
In developing the syllabus in this research, a research and development (R\&D) approach is used, which is guided by the ADDIE model and is carried out in a very limited time. In this case the development of the syllabus of welding technology courses in the first stage, the survey method was used through a needs analysis and literature study. The second stage, designing a draft of the Welding Engineering syllabus. The third stage used the trial method through expert review procedures, one-on-one trials, small group trials, and field trials. In the next stage is the Implementation and Dissemination and evaluation of products. Data collection techniques used in this study were non-test techniques in the form of questionnaire responses from students and expert lecturers. In more detail, the approach and method used is described in the form of a fishbone diagram.

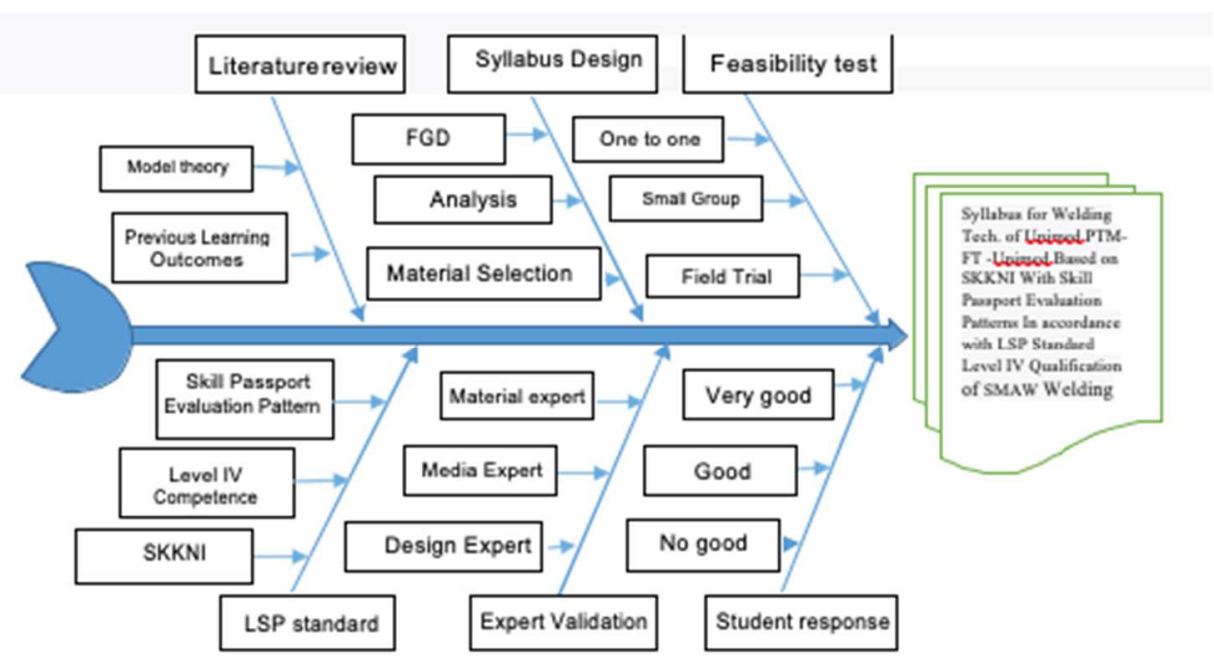

Fig 1. Fishbone Diagram

\section{Result and Discussion}

\section{Analysis (analysis)}

At this stage a need assessment (needs analysis) is carried out to determine the learning process of welding technology that has taken place in the Unimed PTM-FT Study Program and existing infrastructure. Besides that, welding competency data is also traced as standardized according to LSP standards up to level IV with the evaluation pattern of passport skills. Learning process data is obtained from previous research conducted by the KDBK Welding Technology Team with the following results [4]: (1) Learning Process (a) Learning objectives and competencies are not based on the needs of students and industry, (b) Do not use evaluation sheet in assessing the learning process, (c) Learning activities no introduction, presentation, and closing, (d) Initial tests of student ability are not carried out, (e) Lecturer manuals and student manuals are absent, (f) Students and lecturers experiencing obstacles in participating in learning and, (g) Need to develop the learning of welding subjects that are oriented to the needs of the world; (2) Facilities and Infrastructure (a) Adequate lecture room measuring $180 \mathrm{~m} 2$ for 15 welding lecture participants, (b) Workshop facilities are adequate, (c) The weight of the welding subject is 2 credits, 1 meeting 200 minutes with a duration of 16 meetings in 1 semester, (d) 
For students who wish to explore material Welding technology is given elective courses Advanced welding as much as 2 more credits in the following semester, (e) Supporting references available in the Library, mostly in foreign languages and. (f) Diktat and modules available but not yet needs based on du / di Welding competency data up to level IV is obtained by tracing SKKNI. The formulation of the Welder competency package for each level is as follows [3]:

\section{Level I (Certificate 1)}

a. General competency groups: (1) Performing mutual communication, and (2) Identifying the principles of Occupational Safety and Health (K3)

b. Core competency groups: (1) Measuring with basic mechanical measuring instruments, (2) Reading sketches and / or simple working drawings, (3) Using hand tools and light machinery, (4) Carrying out mechanical cutting, (5) Carrying out mechanical cutting gas cutting, (6) Carrying out (basic) welding routines with a manual arc welding process, (7) welding underhand / flat position plates with a manual arc welding process, and (8) welding horizontal / horizontal position plates

c. Specific competency groups: (1) Make a report, and (2) Perform basic technical calculations

\section{Level II (Certificate 2)}

a. General competency groups: (1) Doing work in teams, and (2) Implementing Occupational Safety and Health and the Environment (K3L)

b. Core competency group: (1) Measuring with a precision mechanical measuring instrument, (2) Reading technical drawings and welding symbols, (3) Welding upright /vertical position plates with a manual arc welding process, (4) Welding over head position / overhead plates with the manual arc welding process, (5) Weld the horizontal axis pipe position can be rotated with the manual arc welding process, and (6) Weld the vertical axis position can be rotated

c. Specific competency groups: (1) Interpret English literature, and (2) Operate Computers

\section{Level III (Certificate 3)}

a. General competency groups: (1 Implement a quality system, (2) Plan routine tasks

b. Core competency group: (1) Welding the horizontal axis position pipe cannot be rotated with a manual arc welding process, (2) Welding the oblique axis position pipe cannot be rotated by a manual arc welding process, and (3) Welding the plates and / or pipes of all positions with a manual arc welding (SMAW) process

c. Specific competency groups: (1) Apply material handling, (2) Get to know the characteristics and use of materials, (3) Perform welding machine and equipment maintenance, and (4) Apply welding metallurgy

\section{Level 4 (Certificate 4)}

a. General competency groups with competency units: (1) Carry out workplace preparation, (2) Participate in the quality system

b. Core competency groups with competency units: (1) Lead small work teams, (2) Improve welding results, (3) Identify Welding Procedure Specifications (WPS), (4) Demonstrate welding practices to welder groups / levels below, (5) Making fillet welding connections according to WPS for plate-to- plate welding, pipe to pipe, and pipe plate in accordance with the welding process used, (6) Making groove connections according to WPS for 
plate-to-plate welding and in accordance with welding process used, (7) Making groove weld connections according to WPS for pipe to pipe welding and in accordance with the welding process used.

c. Specific competency groups with competency units: (1) Operate welding machines according to WPS

If observed, the competency package contained in the competency group at each level, it appears that the competencies demanded are closely related to Learning Achievement $(\mathrm{CP})$ in other subjects. Such as measuring competence with basic mechanical measuring instruments, competence in reading sketches and / or simple work drawings, competence in carrying out cutting mechanically, and so on.

\section{Level I}

\begin{tabular}{|c|c|}
\hline $\begin{array}{c}\text { Competency Sequences To Be Applied To Welding } \\
\text { Technology Courses }\end{array}$ & $\begin{array}{l}\text { Prerequisites To follows each level of Welding } \\
\text { competency }\end{array}$ \\
\hline $\begin{array}{l}\text { Identifying the principles of Occupational Safety and } \\
\text { Health }\end{array}$ & \multirow{5}{*}{$\begin{array}{l}\text { 1. Measuring with a basic mechanical measuring } \\
\text { instrument } \\
\text { 2. Read simple sketches and / or work drawings } \\
\text { 3. Using hand tools and light machinery } \\
\text { 4. Carry out mechanical cuts } \\
\text { 5. Carry out cuts with Gas } \\
\text { 6. Perform basic technical calculations }\end{array}$} \\
\hline $\begin{array}{l}\text { Carrying out (basic) welding routines with a manual are } \\
\text { welding process }\end{array}$ & \\
\hline $\begin{array}{l}\text { welding underhand / flat position plates with a manual } \\
\text { are welding process }\end{array}$ & \\
\hline welding horizontal / horizontal position plates & \\
\hline Make a report & \\
\hline
\end{tabular}

\section{Level II}

\begin{tabular}{|c|c|}
\hline $\begin{array}{c}\text { Competency Sequences To Be Applied To Welding } \\
\text { Technology Courses }\end{array}$ & $\begin{array}{l}\text { Prerequisites To follows each level of Welding } \\
\text { competency }\end{array}$ \\
\hline $\begin{array}{l}\text { Welding upright /vertical position plates with a manual } \\
\text { are welding orocess }\end{array}$ & \multirow{4}{*}{$\begin{array}{l}\text { 1. Do work in teams } \\
\text { 2. Measuring with a precision mechanical } \\
\text { measuring instrument } \\
\text { 3. Reading technical drawings and welding } \\
\text { symbols } \\
\text { 4. Interpreting English literature } \\
\text { 5. Operating the Computer }\end{array}$} \\
\hline $\begin{array}{c}\text { Wesaing over nead posituon / overnead ptates witn the } \\
\text { mapual are welding process }\end{array}$ & \\
\hline $\begin{array}{l}\text { Weld the horizontal axis pipe position can be rotated with th } \\
\text { manual are welding process }\end{array}$ & \\
\hline Weld the vertical axis position can be rotated & \\
\hline
\end{tabular}

Level III

\begin{tabular}{|c|c|}
\hline $\begin{array}{c}\text { Competency Sequences To Be Applied To Welding } \\
\text { Technology Courses }\end{array}$ & $\begin{array}{c}\text { Prerequisites To follow each level of Welding } \\
\text { competency }\end{array}$ \\
\hline $\begin{array}{l}\text { Welding the horizontal axis position pipe cannot be rotated } \\
\text { with a manual are welding process, }\end{array}$ & \multirow{4}{*}{$\begin{array}{l}\text { 1. Implement a quality system } \\
\text { 2. Plan routine tasks } \\
\text { 3. Implement material handling } \\
\text { 4. Apply welding metallurgy }\end{array}$} \\
\hline $\begin{array}{l}\text { Welding the oblique axis position pipe cannot be rotated by } \\
\text { a manual are welding process, }\end{array}$ & \\
\hline $\begin{array}{l}\text { Welding the plates and / or pipes of all positions with a } \\
\text { manual are welding (SMAW) process }\end{array}$ & \\
\hline Perform welding machine and equipment maintenance & \\
\hline
\end{tabular}




\section{Level IV}

Competency Sequences To Be Applied To Welding
Technology Courses

The competency package as seen in the composition of the order of competence to be applied to the welding technology courses above, students are required to master certain competencies as a prerequisite to follow each level of welding competency found in other courses.

SKKNI-based Welding Technology Syllabus with passport skill evaluation pattern to support the competency test as described above is still a draft that will be submitted through trials and evaluated as a consequence of the ADDIE Model consisting of five steps namely: 1) Analyse (analysis), conduct need assessment (needs analysis), (2) Design (design), relating to the object of learning, assessment instruments, exercises and their contents, subject analysis, learning plans, and learning media, (3) Development (development), the process of making the design draft into a process reality or product that will be used, (4) Implementation (implementation / execution), which is a concrete step to implement the learning system that we are making and (5) Evaluation (evaluation / feedback), is a process to see whether the learning system that is being built can succeed. The discussion of the SKKNI-based welding technology syllabus as previously designed, is an initial product in this study that still needs further testing. However, it can be assumed that this syllabus draft will be more effectively applied in learning in the context of ownership of welding competencies by students that can support the success in taking the competency test at the certification body in the SMAW welding scheme.

\section{Conclusion}

The Welding Technology Syllabus up to level IV SMAW welding as proposed can be followed by students by first meeting the competency prerequisites as required for each level of competence. To follow the learning at each level, the prerequisites may be in line with the 
implementation of the competencies of each level, but to follow the evaluation at each level, it must be completed following the specified prerequisites Regarding the evaluation items, what is called the Competency Test material (MUK) in the competency test still needs to be developed further in the future as a necessity so that college participants do not experience obstacles when they will take competency tests on the LSP according to the Scheme in the SMAW Welding in accordance with the Level followed

\section{References}

[1] https://industri.kontan.co.id/news/industri-manufaktur-butuh-5000-ahli-las-setahun diunduh 31 Oktober 2019, pukul 05.40 WIB

[2] Peraturan Pemerintah Republik Indonesia Nomor 31 Tahun 2006 Tentang Sistem Pelatihan Kerja Nasional https://mediaindonesia.com/read/detail/212116-indonesia-akanpenuhi kekurang-an-ahli-pengelasan-bertaraf-internasional, diunduh 27 Mei 2019 pukul 04.55

[3] Kepmenakertrans RI Nomor : KEP. 342/MEN/X/2007, Tentang Penetapan SKKNI Sektor Industri Pengolahan Sub Sektor Industri Barang Jadi Dari Logam Bidang Jasa Industri Pengelasan Sub Bidang Pengelasan SMAW

[4] Khoiri, dkk. Pengembangan Modul Teknologi Pengelasan Untuk Menganalisis Kekuatan Sambungan Las Berbasis Kebutuhan Dunia Usaha dan Industri. Laporan Penelitian $K D B K$. Medan : FT Unimed. (2018)

[5] ._. Panduan Penyusunan Kurikulum Tingkat Satuan Pendidikan Jenjang Pendidikan Dasar dan Menengah. Jakarta: Badan Standar Pendidikan Nasional. (2006)

[6] Branch, R. M. Instructional Design: The ADDIE Approach. Boston: Springer US. (2009)

[7] Robert M. Gagne, et.al. Principle of Instructional Design, Fifth Edition. New Jersey, USA: Thomson Wadsworth. (2015)

[8] Sugiyono. Metode Penelitian Kuantitatif, Kualitatif Dan R\&D. Bandung: Alfabeta. (2008)

[9] Sulistio. Pengembangan perangkat evaluasi belajar mahasiswa pada mata kuliah praktikum kelistrikan otomotif model pbi di jurusan teknik mesin ft Unesa. Surabaya: Universitas Negeri Surabaya. (2010) 